\title{
Brazilian dentists' perceptions of using bone grafts: an inland survey
}

\author{
Lana K. Araújo',2, Gustavo S. Antunes', Marcelo M. Melo², Igor I. Castro-Silva1,2 \\ 1. Universidade Federal do Ceará, Campus de Sobral, Faculdade de Odontologia/Clínica integrada, Sobral, Ceará, Brasil. \\ 2. Universidade Federal do Ceará, Campus de Sobral, Programa de Pós-graduação em Biotecnologia/Biomateriais e \\ biocompatibilidade, Sobral, Ceará, Brasil.
}

\begin{abstract}
Pre-clinical assessments of bone substitute materials are frequent in the literature, but research papers about the clinical situation of bone graft use and consumer market acceptance are rare. The aim of this study was to evaluate the dental use of bone grafts according to the perception of dentists in the city of Sobral, Brazil. We interviewed 183 professionals and analyzed their professional data, knowledge of the subject, specific use, and opinions on cost-effectiveness and biosafety. Most of the respondents had 10 years' or less experience in the profession, and lacked specialization though they had been familiar with the subject since they graduated. The most frequently mentioned compositions were ceramics, followed by composites. Only a quarter of the respondents had performed bone grafts, generally with up to 50 cases, with the most frequent applications being using simultaneously with a dental implant, fresh dental sockets and maxillary sinus lifting. Autogenous and xenogeneic grafts were more frequent than alloplastic and allogeneic; ceramics were the most frequently used composition, and the association
\end{abstract}

of bone graft with membrane was more frequent than bone graft alone or associated with autologous fibrin. Professional and patient satisfaction was high, cost was considered moderate, and differences were found regarding patient participation in the choice and country of origin of the product. Bone grafts were used more often in the private than public service. Dentists stated that they follow the instructions. Inflammatory or infectious complications were found to be related to the frequency of the procedure performed and safety regarding the origin. Opinions were favorable regarding the use of grafts derived from animals and unfavorable to grafts derived from cadavers. Very few respondents were registered in human bone tissue banks. The good level of acceptance for dental use of bone grafts in a Brazilian inland city provides a promising scenario for the development of the sector.

Received: March 2020; Accepted: August 2020.

Keywords: bone transplantation - biocompatible materials bone regeneration.

\section{Uso de enxertos ósseos na percepção de cirurgiões-dentistas do interior do Brasil}

\begin{abstract}
RESUMO
Avaliações pré-clínicas sobre materiais osseosubstitutos são frequentes na literatura, mas são raras pesquisas sobre o panorama clínico de uso de enxertos ósseos e aceitação do mercado consumidor. O objetivo deste estudo foi avaliar o uso odontológico de enxertos ósseos na percepção de dentistas da cidade de Sobral, Brasil. Foram entrevistados 183 profissionais e analisados dados profissionais, conhecimento temático, uso especifico, relação custo-efetividade e biossegurança. A maioria dos cirurgiões-dentistas exibiu até 10 anos na profissão, ausência de especialização, porém familiaridade com a temática desde a graduação. As cerâmicas, seguidas de compósitos, compuseram as composições mais citadas. Apenas um quarto dos cirurgiões-dentistas já realizaram enxertos ósseos, em geral com realização de até 50 casos, com maior tendência de aplicação em alvéolo dentário fresco, simultânea a implante dentário e para levantamento de seio maxilar. As origens autógena exenógena tiveram maior destaque do que aloplástica e alógena, as cerâmicas foram a composição mais usada e a associação do
\end{abstract}

enxerto ósseo com membrana foi mais frequente do que enxerto ósseo sozinho ou associado à fibrina autóloga. A satisfação do profissional e paciente foi alta, o custo considerado moderado, havendo diferenças quanto a participação do paciente na escolha e no país de origem do produto, com maior uso no serviço privado do que no público. Os dentistas afirmaram seguirem a bula, que as complicações inflamatórias ou infecciosas estão relacionadas com a frequência de procedimento realizado e segurança quanto à origem. Houve opinião favorável ao uso de enxertos derivados de animais e desfavorável ao de cadáveres, havendo raros profissionais cadastrados em bancos de tecidos ósseos humanos. A boa aceitação para uso odontológico de enxertos ósseos em cidade do interior do Brasil configura um cenário promissor para o desenvolvimento do setor.

Palavras-chave: transplante ósseo - materiais biocompativeis regeneração óssea. 


\section{INTRODUCTION}

Bone regeneration in the human body has been studied over the past century with a wide variety of purposes, approaches and surgical materials ${ }^{1}$. Bone grafts are indicated in medical and dental practice for restoring compromised function and aesthetics due to bone defects ${ }^{2}$. In oral surgery, bone grafts contribute to the treatment of small to moderate bone defects resulting from periodontal or endodontic disease, dental socket filling after extraction, maxillary sinus lifting or rehabilitation of bone atrophy prior to implants, and even large bone defects caused by traumas, congenital deformities, pathologies and infections involving the maxillofacial complex ${ }^{3}$.

The choice of a bone substitute should be guided by its physicochemical, mechanical and biological characteristics, including architecture, porosity, resistance, biocompatibility, biodegradability, osteoconduction, osteoinduction and/or osteogenesis, in order to mimic the bone tissue to be repaired $^{4}$. Biomaterials can be classified according to their origin (autogenous, allogeneic, xenogeneic or alloplastic), composition (metals and alloys, ceramics and bio-glass, polymers or composites) or interaction with the biological environment (bioinert, bioabsorbable or bioactive) . $^{5}$.

There are advantages and limitations in the use of bone grafts. Higher success rates have been achieved with autogenous bone, despite its limited supply and higher morbidity ${ }^{5,6}$. Donated allografts are more readily available, having been reported over the last sixty years and used increasingly Europe. However, difficulties in processing the biomaterial and risk of an immunogenic inflammatory response may reflect delay or decrease in osteogenesis ${ }^{6}$. Xenografts have been popular since the 1960s, especially bovine bone, despite the controversies with relation to the risk of transmission of xenozoonoses, which, in fact, have never been documented in dental practice? Currently, animal byproducts could subsidize the generation of natural materials and contribute to the consolidation of a sustainable industry ${ }^{8}$. Alloplastic materials are satisfactory alternatives to natural materials, but face the challenge of controlling the great variability of results depending on their composition, associated with resorption and inflammatory or repair responses ${ }^{9}$. In view of this evidence, there is still no ultimate or single biomaterial for bone reconstruction, which motivates the biotechnological development of the sector ${ }^{10}$.
The growth of the industry and the consumer market for bone substitute materials for dental use converges with the higher life expectancy of the population and the increase in purchasing power in developing countries ${ }^{11}$. This market is markedly significant in North America, followed by Europe, Asia, Latin America, Oceania and Africa ${ }^{12}$. A worldwide increase of $4.4 \%{ }^{13}$ to $9.5 \%{ }^{12}$ is estimated for the period from 2018 to 2026 in guided bone regeneration procedures involving bone grafts and membranes, which may be associated with greater clinical demand from both professionals and patients seeking better results ${ }^{13}$. In the United States and Europe, more than half a million people annually receive treatment for bone defect repair, and the international bone graft market moved USD 493 million in 2018 and expects to generate USD 931 million by $2025^{14}$. In Latin America, this market was valued at USD 116.8 million in $2018^{15}$. In Brazil, the political and economic crisis in the country and the bureaucracy involved in opening new companies are expected to delay the growth of this sector ${ }^{13}$. In a price-sensitive market, the costs and benefits of bone graft procedures should be considered for clinical choice ${ }^{16}$.

In this broad market scenario, there is a lack of evidence in the literature about the permeability to bone grafts in dental practice in medium and small cities. The city of Sobral, located in the interior of the State of Ceara, northeastern Brazil ( $3^{\circ} 41^{\prime} 42.0^{\prime \prime} \mathrm{S}$ $40^{\circ} 20^{\prime} 28.3^{\prime \prime} \mathrm{W}$ ) is located $232 \mathrm{~km}$ from the state capital, Fortaleza. It has an estimated population of 208,935 , being the fifth-largest city in this Brazilian state, with a rate of $24.6 \%$ of professional occupation, average of 2 minimum monthly wages, gross domestic product per capita of R \$ 20,258.09 or USD 4,771.08, municipal human development index of $0.714,88.35 \%$ of urban population, $67.83 \%$ in the 15- to 64-year age group and Gini index $0.56^{17}$. There are 39 outpatient units with dental care, 1 emergency facility with maxillofacial surgery ${ }^{17}, 44$ oral health teams in primary care, 2 dental specialty centers (1 municipal and 1 regional) in secondary care $^{18}$ and 2 schools of dentistry (1 public and 1 privative) with dental care for the population. In the Sobral Campus of the Federal University of Ceara, it was estimated that in 2019 , about 4,000 procedures involving oral surgery, periodontics or implantology were performed at the dental clinic.

Thus, the aim of this study was to assess the general 
profile of use of bone grafts in the perception of dentists in the Brazilian inland.

\section{MATERIALS AND METHODS}

\section{Ethical and legal aspects}

This research adopted the ethical principles of respect for people, non-maleficence, beneficence and justice described in the Belmont Report (1978) and the Brazilian guidelines of the Resolution of the National Health Council No. 466 (2012), which establishes the basic requirements for research involving human beings in the country. This research was assessed and approved by the local Ethics Committee of the Universidade Estadual Vale do Acarau via Plataforma Brasil (register CAAE \#04644918.4.0000.5053 and approval protocol \#3.145.268), before data collection started.

Participants' consent was registered through a Free and Informed Consent Form (FICF), which provided information in appropriate language about the purpose of the research, as well as ensuring the confidentiality of identities.

\section{Type of study}

This was an exploratory, descriptive, crosssectional study by intensive direct observation with a quantitative, structured approach. The target population consisted of dentists working in the city of Sobral.

\section{Sample}

In a previous consultation with the Federal Council of Dentistry, which is a professional-class entity responsible for managing all enrollments and the legality of dental practice in Brazil, it was informed that there are 233 registered practitioners in the city of Sobral. Considering a population of 233 dentists in the city of Sobral and calculating a representative sample with $99 \%$ confidence interval and 5\% margin of error, we idealized a sample of 173 dentists.

To achieve significant, homogeneous sampling, a random field study was conducted from February to September 2019, restricted to the Sobral municipality, using the snowball technique to access these professionals.

Inclusion criteria were dentists working in the city of Sobral, in private practice or public assistance in primary, secondary or tertiary care of the Brazilian Unified Health System, duly registered with the
Federal Council of Dentistry, of legal age (over 18 years old), of either sex, with no limitation regarding year of graduation, and who accepted to participate voluntarily in this study. Professionals who did not sign the FICF or cases of error in filling out forms were excluded.

\section{Data collection}

For the standardization of data collection and analysis, an anonymous, self-reported, face-to-face form was used, applied in individual voluntary interviews in a dental office or health unit.

The variables considered in this study were based on the methodology developed by Castro-Silva and Coutinho $(2012)^{19}$. The form consisted of closed objective or semi-open questions, grouped into five basic categories (professional data, subject knowledge, specific use, cost-effectiveness and biosafety).

\section{Data analysis}

After the generation of an electronic bank with data collected in the Excel for Windows software (Office $2010^{\mathrm{TM}}$, Microsoft Corporation, USA), the quantitative variables were described in terms of absolute and relative values, being presented in the form of a table. Intergroup inferential statistical analysis of frequencies was performed using the Statistical Package for the Social Sciences software version 20 (IBM ${ }^{\mathrm{TM}}$, USA) applying the chi-square test and Fisher's exact post-test for nonparametric data, considering significant differences if $\mathrm{P}<0.05$.

\section{RESULTS}

Among the 233 dentists in the city of Sobral, a total 183 volunteers comprised the sample, equivalent to $78.54 \%$ of the city's professionals. Remarkably, the sample used in this study was greater than the size determined using statistical parameters as mentioned above. The representative sample of dentists in this study increases the level of confidence in the results found for the city of Sobral.

The prevalence of females (117 participants) was almost double that of males (66 participants) (Fig. 1A). Mean age \pm standard deviation was $35.37 \pm 10.21$ years and there was prevalence of three quarters of the sample in the age group up to 40 years (Fig. 1B). The vast majority of the sample did not have any specialization or expertise in Orthodontics (Fig. 1C). Table 1 shows respondents' general knowledge about 


\section{A-Gender}

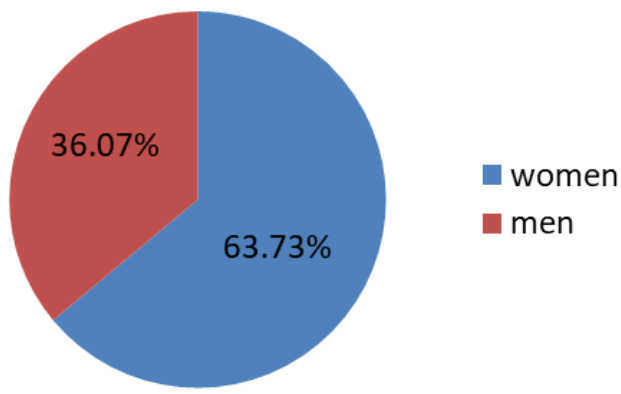

B - Age range

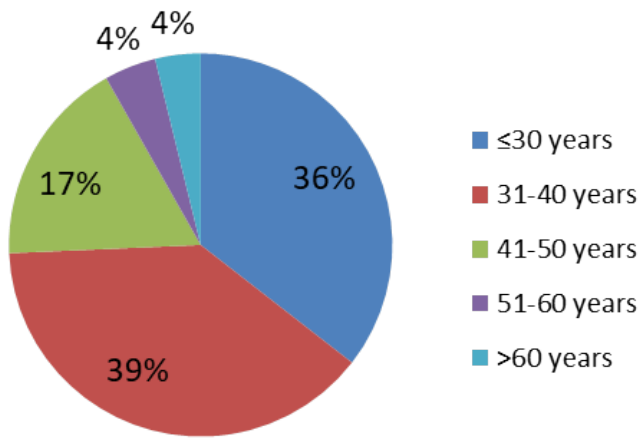

\section{C-Dental specialties*}

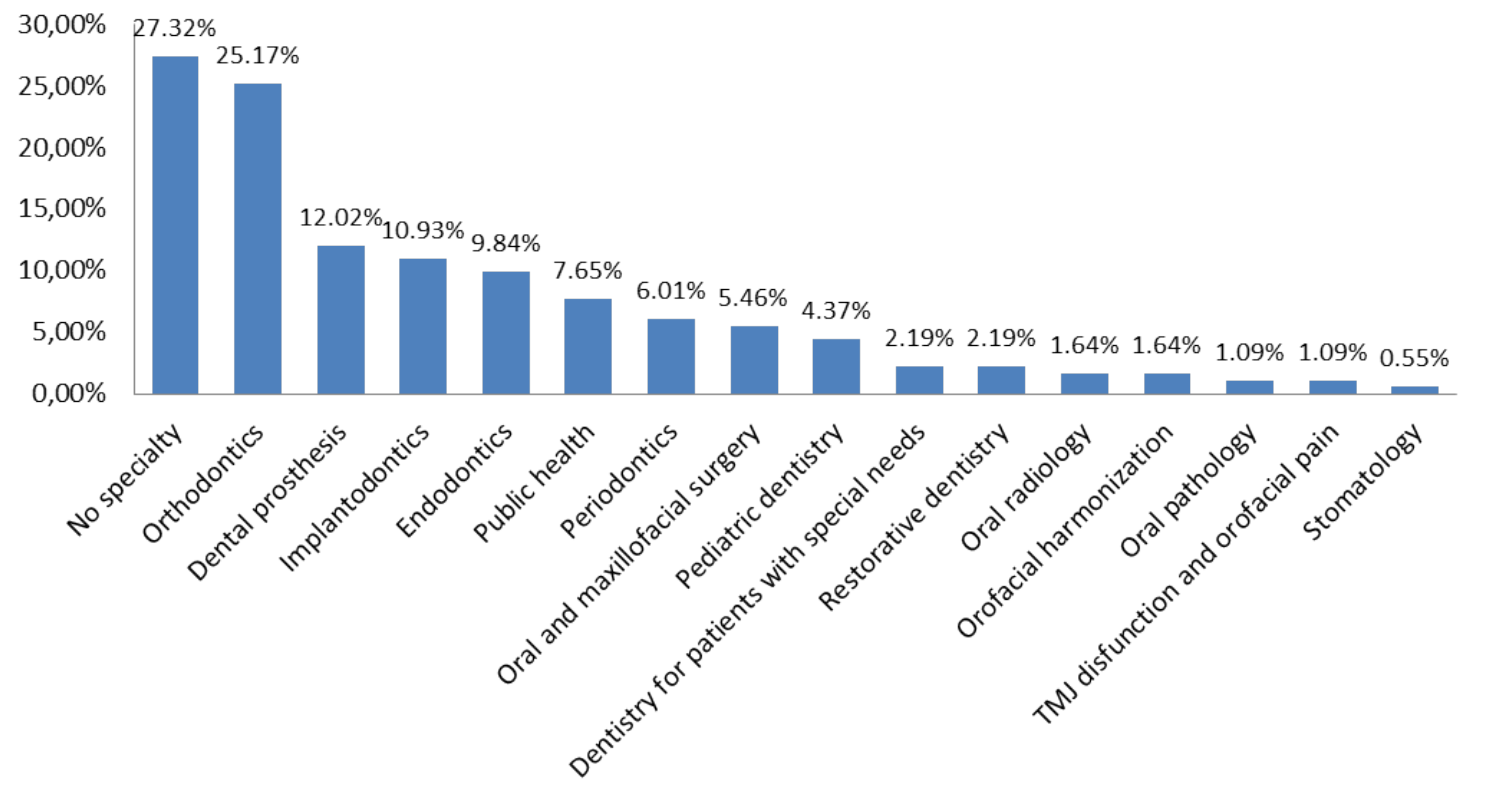

Fig. 1: Profile of dentists in the city of Sobral, Brazil $(n=183)$

bone grafts. Most respondents sample had graduated up to 10 years previously and demonstrated significant familiarity with the subject. They had acquired such knowledge mainly at undergraduate level, in comparison to postgraduate studies and dental conferences. Among the natural or synthetic compositions mentioned, ceramics were the most prevalent, followed by composites, while there was little mention of polymers and glasses. Bovine mineral bone was the material most frequently cited by all participants.

Table 2 shows that only a quarter of the respondents (45 or $24.59 \%$ ) had performed bone grafts. Regardless of the intensity of use (from $\leq 10$ to $>100$ cases), the most frequent bone graft applications were simultaneously with a dental implant, fresh dental sockets and maxillary sinus lifting, while the least frequent were periodontal use, paraendodontic use and extensive bone reconstruction. Autogenous and xenogeneic grafts were more often used than alloplastic and allogeneic grafts. Ceramics were the most frequently used composition of bone grafts and their association with membrane was more frequent than bone graft alone or associated with autologous fibrin.

Table 3 shows the high satisfaction of professionals and patients with bone grafts, with material or technical costs being considered moderate. 
Table 1. Knowledge about the subject of bone grafts among dentists in Sobral, Brazil $(n=183)$.

\begin{tabular}{|c|c|c|c|c|c|c|c|}
\hline Variable & Categories & & equency of $t$ & ne since gr & luation (y & & $\mathbf{P}^{\star \star *}$ \\
\hline $\begin{array}{l}\text { Knowledge about } \\
\text { bone grafts or } \\
\text { bone substitute } \\
\text { biomaterials }\end{array}$ & $\begin{array}{l}\text { None } \\
\text { Yes, in undergraduate level } \\
\text { Yes, in postgraduate studies } \\
\text { Yes, at dental conferences }\end{array}$ & $\begin{array}{c}\leq 10 \\
1(0.55 \%) \\
88(48.09 \%) \\
41(22.40 \%) \\
15(8.20 \%)\end{array}$ & $\begin{array}{c}\frac{11-20}{0} \\
34(18.58 \%) \\
35(19.13 \%) \\
16(8.74 \%)\end{array}$ & $\begin{array}{c}\frac{21-30}{1(0.55 \%)} \\
7(3.83 \%) \\
11(6.01 \%) \\
4(2.19 \%)\end{array}$ & $\begin{array}{c}\frac{31-40}{0} \\
0 \\
4(2.19 \%) \\
5(2.73 \%)\end{array}$ & $\begin{array}{c}\frac{20}{0} \\
0 \\
3(1.64 \%) \\
3(1.64 \%)\end{array}$ & $<0.01$ \\
\hline $\begin{array}{l}\text { Citation of } \\
\text { bone grafts (by } \\
\text { composition) }\end{array}$ & $\begin{array}{l}\text { Ceramics } \\
\text { Glasses } \\
\text { Polymers } \\
\text { Composites }\end{array}$ & $\begin{array}{c}59(32.24 \%) \\
1(0.54 \%) \\
2(1.09 \%) \\
30(16.39 \%)\end{array}$ & $\begin{array}{c}57(31.15 \%) \\
1(0.54 \%) \\
4(2.18 \%) \\
15(8.20 \%)\end{array}$ & $\begin{array}{c}12(6.55 \%) \\
0 \\
2(1.09 \%) \\
9(4.92 \%)\end{array}$ & $\begin{array}{c}0 \\
0 \\
0 \\
2(1.09 \%)\end{array}$ & $\begin{array}{c}3(1.64 \%) \\
0 \\
1(0.54 \%) \\
1(0.54 \%)\end{array}$ & 0.22 \\
\hline
\end{tabular}

Table 2. Specific use of bone grafts by dentists in Sobral, Brazil $(n=45)$.

\begin{tabular}{|c|c|c|c|c|c|c|}
\hline \multirow{2}{*}{$\begin{array}{l}\text { Variable } \\
\text { Application* }\end{array}$} & \multirow[b]{2}{*}{$\begin{array}{l}\text { Categories } \\
\text { Fresh dental socket } \\
\text { Simultaneously with a dental implant } \\
\text { After periodontal treatment } \\
\text { Maxillary sinus lifting } \\
\text { Paraendodontic surgery } \\
\text { Extensive bone reconstruction }\end{array}$} & \multicolumn{4}{|c|}{ Frequency of bone grafts (cases) } & \multirow{2}{*}{$\begin{array}{l}\mathbf{P}^{\star *} \\
0.85\end{array}$} \\
\hline & & $\begin{array}{c}\leq 10 \\
14(31.11 \%) \\
17(37.78 \%) \\
7(15.56 \%) \\
13(28.89 \%) \\
2(4.44 \%) \\
5(11.11 \%)\end{array}$ & $\begin{array}{c}\underline{11-50} \\
8(17.78 \%) \\
10(22.22 \%) \\
5(11.11 \%) \\
7(15.56 \%) \\
3(6.67 \%) \\
2(4.44 \%)\end{array}$ & $\begin{array}{l}\underline{51-100} \\
2(4.44 \%) \\
3(6.67 \%) \\
1(2.22 \%) \\
3(6.67 \%) \\
1(2.22 \%) \\
3(6.67 \%)\end{array}$ & $\begin{array}{c}>100 \\
7(15.56 \%) \\
6(13.33 \%) \\
0(0 \%) \\
7(15.56 \%) \\
2(4.44 \%) \\
4(8.89 \%)\end{array}$ & \\
\hline Origin* & $\begin{array}{l}\text { Autogenous } \\
\text { Allogeneic } \\
\text { Xenogeneic } \\
\text { Alloplastic }\end{array}$ & $\begin{array}{c}10(22.22 \%) \\
4(8.89 \%) \\
13(28.89 \%) \\
5(11.11 \%)\end{array}$ & $\begin{array}{c}9(20 \%) \\
1(2.22 \%) \\
10(22.22 \%) \\
2(4.44 \%)\end{array}$ & $\begin{array}{l}3(6.67 \%) \\
1(2.22 \%) \\
2(4.44 \%) \\
2(4.44 \%)\end{array}$ & $\begin{array}{c}6(13.33 \%) \\
0 \\
6(13.33 \%) \\
2(4.44 \%)\end{array}$ & 0.86 \\
\hline Composition* & $\begin{array}{l}\text { Ceramics } \\
\text { Glasses } \\
\text { Polymer } \\
\text { Composites }\end{array}$ & $\begin{array}{c}24(53.33 \%) \\
0 \\
2(4.44 \%) \\
5(11.11 \%)\end{array}$ & $\begin{array}{c}16(35.55 \%) \\
1(2.22 \%) \\
0 \\
4(8.89 \%)\end{array}$ & $\begin{array}{c}9(20 \%) \\
0 \\
1(2.22 \%) \\
1(2.22 \%)\end{array}$ & $\begin{array}{c}16(32.55 \%) \\
0 \\
1(2.22 \%) \\
2(4.44 \%)\end{array}$ & 0.80 \\
\hline Association* & $\begin{array}{l}\text { Bone graft alone } \\
\text { Bone graft+Cement } \\
\text { Bone graft+Membrane } \\
\text { Bone graft+Autologous fibrin }\end{array}$ & $\begin{array}{c}9(20 \%) \\
0 \\
20(44.44 \%) \\
3(6.67 \%)\end{array}$ & $\begin{array}{c}5(11.11 \%) \\
0 \\
9(20 \%) \\
3(6.67 \%)\end{array}$ & $\begin{array}{c}2(4.44 \%) \\
0 \\
3(6.67 \%) \\
2(4.44 \%)\end{array}$ & $\begin{array}{c}5(11.11 \%) \\
1(2.22 \%) \\
6(13.33 \%) \\
5(11.11 \%)\end{array}$ & 0.53 \\
\hline
\end{tabular}

However, the fact that professionals never or rarely include the patient in the choice of this form of treatment is remarkable. The reported country of origin of the bone graft used differed significantly according to how many bone grafts the respondent had performed: most of those who had performed up to 10 cases did not know country of origin or had used imported material, while respondents who had performed over 50 cases reported using imported or imported + national materials. Use of bone grafts was higher in the private service than in the public for most of the analyzed ranges.

Table 4 shows that professionals always follow datasheets and recommendations for the use of bone grafts. Respondents who had performed up to 50 cases did not overall report having patients with inflammatory or infectious complications after bone grafts, while the profile is significantly reversed for respondents who had performed more than 50 cases, although they reported feeling safe regarding the origin of the materials. In general, both the opinion of the professionals and their perception of the belief of their patients were more favorable to the use of bone grafts from animals than from humans. Within all three dental specialties, the low number of professionals registered in the Brazilian Transplant System for use of bone tissue banks confirms the low level of acceptance among professionals of allografts, with only 2 registered dentists in the specialties of Oral and Maxillofacial surgery or Implantodontics.

\section{DISCUSSION}

The local register of 233 dentists for a population of 208,935 inhabitants in Sobral ${ }^{17}$ shows the ratio of 1 professional to 896 individuals, which is a lower rate 
Table 3. Cost-effectiveness of bone grafts for dentists in Sobral, Brazil $(n=45)$.

Variable

Professional satisfaction

\begin{tabular}{|c|c|}
\hline & $\begin{array}{l}\text { Yes } \\
\text { No } \\
\text { Don't know }\end{array}$ \\
\hline Patient satisfaction & $\begin{array}{l}\text { Yes } \\
\text { No } \\
\text { Don't know }\end{array}$ \\
\hline Material or technical costs & $\begin{array}{l}\text { Low } \\
\text { Moderate } \\
\text { High } \\
\text { Don't know }\end{array}$ \\
\hline $\begin{array}{l}\text { Patient participates in the } \\
\text { choice }\end{array}$ & $\begin{array}{l}\text { Always } \\
\text { Often } \\
\text { Rarely } \\
\text { Never } \\
\text { Don't know }\end{array}$ \\
\hline Country of origin & $\begin{array}{l}\text { National } \\
\text { Imported } \\
\text { National+Importe } \\
\text { Don't know }\end{array}$ \\
\hline
\end{tabular}

Service*

Public

Private
Categories

Frequency of bone grafts (cases)

\begin{tabular}{c|c|c|c}
$\stackrel{110}{24(53.33 \%)}$ & $11(24.44 \%)$ & $\frac{51-100}{3(6.67 \%)}$ & $7(15.55 \%)$
\end{tabular}

$\begin{array}{ll}0 & 0 \\ 0 & 0\end{array}$

\begin{tabular}{|l|l|l|l|}
\hline $24(53.33 \%)$ & $11(24.44 \%)$ & $3(6.67 \%)$ & $7(15.55 \%)$
\end{tabular}

\begin{tabular}{c|c}
0 & 0 \\
0 & 0
\end{tabular}

$1(2.22 \%) \quad 1(2.22 \%)$

$11(24.44 \%) \quad 5(11.11 \%)$

$1(2.22 \%) \quad 5(11.11 \%)$

$1(2.22 \%)$

$4(8.89 \%)$

$5(11.11 \%)$

$3(6.67 \%)$

$11(24.44 \%)$

$1(2.22 \%)$

0

$3(6.67 \%)$

$3(6.67 \%)$

$3(6.67 \%)$

$2(4.44 \%)$

$3(6.67 \%)$

0

12(26.67\%) 2(4.44\%)

$6(13.33 \%) \quad 6(13.33 \%)$

$13(28.89 \%)$

0

$11(24.44 \%) \quad 3(6.67 \%)$

$19(42.22 \%) \quad 11(24.44 \%)$
0

0

0

$3(6.67 \%)$

0

(2.22\%)

0

$1(2.22 \%)$

$1(2.22 \%)$

0

0

$2(4.44 \%)$

$1(2.22 \%)$

0

2(4.44\%)

$3(6.67 \%)$
P*

1.00

1.00

0

0

$6(13.33 \%)$

$1(2.22 \%)$

0.40

$1(2.22 \%)$

2(4.44\%)

0

$4(4.44 \%)$

0

0

$5(11.11 \%)$

$2(4.44 \%)$

0

$2(4.44 \%)$

$7(15.55 \%)$

0.02

${ }^{*}$ Statistical chi-square test

Table 4. Biosafety of bone grafts for dentists in Sobral, Brazil $(n=45)$.

\begin{tabular}{|c|c|c|c|c|c|c|}
\hline Variable & Categories & Frec & quency of bo & e grafts (c & es) & $\mathbf{P}^{\star \star *}$ \\
\hline $\begin{array}{l}\text { Professionals always follow } \\
\text { datasheets and recommendations }\end{array}$ & $\begin{array}{l}\text { Never } \\
\text { Always } \\
\text { Sometimes } \\
\text { Don't know }\end{array}$ & $\begin{array}{c}\leqq 10 \\
0 \\
21(46.67 \%) \\
2(4.44 \%) \\
1(2.22 \%)\end{array}$ & $\begin{array}{c}\frac{11-50}{0} \\
11(24.44 \%) \\
0 \\
0\end{array}$ & $\begin{array}{c}\frac{51-100}{0} \\
3(6.67 \%) \\
0 \\
0\end{array}$ & $\begin{array}{c}\geq 100 \\
0 \\
6(13.33 \%) \\
1(2.22 \%) \\
0\end{array}$ & 0.86 \\
\hline $\begin{array}{l}\text { Patients with inflammatory or } \\
\text { infectious complications after } \\
\text { bone grafts }\end{array}$ & $\begin{array}{l}\text { No } \\
\text { Yes } \\
\text { Don't know }\end{array}$ & $\begin{array}{c}19(42.22 \%) \\
4(8.89 \%) \\
1(2.22 \%)\end{array}$ & $\begin{array}{c}6(13.33 \%) \\
5(11.11 \%) \\
0\end{array}$ & $\begin{array}{c}1(2.22 \%) \\
2(4.44 \%) \\
0\end{array}$ & $\begin{array}{c}1(2.22 \%) \\
6(13.33 \%) \\
0\end{array}$ & 0.04 \\
\hline $\begin{array}{l}\text { Professional feels safe regarding } \\
\text { the origin }\end{array}$ & $\begin{array}{l}\text { No } \\
\text { Yes } \\
\text { Don't know }\end{array}$ & $\begin{array}{c}1(2.22 \%) \\
21(46.67 \%) \\
2(4.44 \%)\end{array}$ & $\begin{array}{c}1(2.22 \%) \\
10(22.22 \%) \\
0\end{array}$ & $\begin{array}{c}0 \\
3(6.67 \%) \\
0\end{array}$ & $\begin{array}{c}0 \\
7(15.55 \%) \\
0\end{array}$ & 0.83 \\
\hline $\begin{array}{l}\text { Professional favorable to use of } \\
\text { bone graft from animals }\end{array}$ & $\begin{array}{l}\text { No } \\
\text { Yes } \\
\text { Don't know }\end{array}$ & $\begin{array}{c}3(6.67 \%) \\
19(42.22 \%) \\
2(4.44 \%)\end{array}$ & $\begin{array}{c}0 \\
11(24.44 \%) \\
0\end{array}$ & $\begin{array}{c}0 \\
3(6.67 \%) \\
0\end{array}$ & $\begin{array}{c}0 \\
7(15.55 \%) \\
0\end{array}$ & 0.55 \\
\hline $\begin{array}{l}\text { Patient favorable to use of bone } \\
\text { graft from animals }\end{array}$ & $\begin{array}{l}\text { No } \\
\text { Yes } \\
\text { Don't know }\end{array}$ & $\begin{array}{c}4(8.89 \%) \\
9(20.00 \%) \\
11(24.44 \%)\end{array}$ & $\begin{array}{c}1(2.22 \%) \\
8(17.78 \%) \\
2(4.44 \%)\end{array}$ & $\begin{array}{c}0 \\
2(4.44 \%) \\
1(2.22 \%)\end{array}$ & $\begin{array}{l}1(2.22 \%) \\
5(11.11 \%) \\
1(2.22 \%)\end{array}$ & 0.44 \\
\hline $\begin{array}{l}\text { Professional favorable to use of } \\
\text { bone graft from human beings }\end{array}$ & $\begin{array}{l}\text { No } \\
\text { Yes } \\
\text { Don't know }\end{array}$ & $\begin{array}{l}9(20.00 \%) \\
7(15.55 \%) \\
8(17.78 \%)\end{array}$ & $\begin{array}{l}5(11.11 \%) \\
4(8.89 \%) \\
2(4.44 \%)\end{array}$ & $\begin{array}{l}1(2.22 \%) \\
1(2.22 \%) \\
1(2.22 \%)\end{array}$ & $\begin{array}{l}3(6.67 \%) \\
3(6.67 \%) \\
1(2.22 \%)\end{array}$ & 0.95 \\
\hline $\begin{array}{l}\text { Registration in the Brazilian } \\
\text { Transplant System* }\end{array}$ & $\begin{array}{l}\text { OMS** } \\
\text { Implantodontics } \\
\text { Periodontics }\end{array}$ & $\begin{array}{c}1(2.22 \%) \\
0 \\
0\end{array}$ & $\begin{array}{l}0 \\
0 \\
0\end{array}$ & $\begin{array}{l}0 \\
0 \\
0\end{array}$ & $\begin{array}{c}1(2.22 \%) \\
1(2.22 \%) \\
0\end{array}$ & 0.39 \\
\hline $\begin{array}{l}\text { Patient favorable to use of bone } \\
\text { graft from human beings }\end{array}$ & $\begin{array}{l}\text { No } \\
\text { Yes } \\
\text { Don't know }\end{array}$ & $\begin{array}{c}9(20.00 \%) \\
1(2.22 \%) \\
14(31.11 \%)\end{array}$ & $\begin{array}{l}2(4.44 \%) \\
2(4.44 \%) \\
7(15.55 \%)\end{array}$ & $\begin{array}{c}1(2.22 \%) \\
0 \\
2(4.44 \%)\end{array}$ & $\begin{array}{c}3(6.67 \%) \\
0 \\
4(8.89 \%)\end{array}$ & 0.65 \\
\hline
\end{tabular}


than the Brazilian average of 1 dental professional to 668 inhabitants $^{20}$. Even in the face of favorable demand, the low number of experts would explain the generalist profile of dentists in the city and may explain the low use of bone grafts in the sample.

Inorganic bioceramics were bone substitute materials most frequently cited and used by respondents, in agreement with most studies on the subject ${ }^{9,21,22}$. This preference is supported by osteoconductive action, ability to carry osteogenic cells $\mathrm{s}^{9,21}$ or osteoinductive growth factors ${ }^{23}$, versatility of concentrations, formats and particle sizes ${ }^{22}$ as well as the possible association of apatites with collagen or other polymers with the aim of achieving biological synergism ${ }^{15,21,24}$. Thus, the basic understanding of the properties of biomaterials for bone regeneration and their appropriate applications is very important in making a good clinical choice ${ }^{19}$.

The most frequent clinical applications were simultaneous use with a dental implant, fresh dental sockets and maxillary sinus lifting, in agreement with the two most prevalent surgical beds in the dental literature ${ }^{19,24,25}$. The present study found a higher frequency of bone graft in association with membranes or autologous fibrin than in isolated form, disagreeing with another Brazilian study ${ }^{19}$ and international reports, which state that dentists make less use of membranes next to the bone graft because it represents an additional cost to the patient ${ }^{16,26}$. The adjunct use of autologous fibrin has been promising, as it has a high concentration of angiogenic and osteogenic growth factors, evidencing the evolution of bone regeneration techniques ${ }^{27}$.

The prevalence of use of autogenous and xenogeneic grafts compared to alloplastic and allogeneic, associated with a more favorable perception of the use of bone grafts from animals than from humans, agrees with other studies on the topic ${ }^{19,28}$. Autografts are a gold standard for the treatment of bone defects ${ }^{28}$, but the preference of professionals for xenografts and alloplastic grafts has increased gradually in Latin America ${ }^{15}$ and Brazil ${ }^{26}$ for medical and dental applications ${ }^{3,22}$. The advantages of xenografts and alloplastic grafts are biomimicry of human bone tissue $^{24}$ and absence of patient's donor bed, which explains their wide range of clinical uses ${ }^{9,19,22}$. Stigmatization of the cadaverous source, lack of disclosure $^{29}$ and ethical, moral or religious values of users could explain low choice of allografts ${ }^{30,31}$.

Satisfaction with bone grafts in this study was high, confirming an Indian study with $59 \%$ of utilization ${ }^{31}$. Refusal rates to bone grafts has been more often associated to the geopopulational context than to age, gender, education and religion, ranging from $2 \%$ for alloplastic grafts to $20 \%$ for allografts in Chilean study ${ }^{30}$ or from $11 \%$ for autografts to $67 \%$ for xenografts in Saudi Arabia ${ }^{29}$.

The present study confirmed the existing knowledge on use of materials of imported ${ }^{12,13}$ or national origin ${ }^{24}$. Multinational companies, predominantly US, currently dominate the global market for dental bone grafts $^{12,13}$. Brazilian industry gains representation among companies already consolidated in the market, with 3 out of 5 institutions responsible for $65 \%$ of dental bone grafts in the country ${ }^{26}$.

Costs were considered moderate by the respondents, predominantly from private practice in Sobral, a finding similar to those from a large city in southeastern Brazil ${ }^{19}$. However, the country suffers from chronic underfunding in public health ${ }^{32}$, where the costs of procedures can be substantial limitations ${ }^{13,33}$ and only a small percentage of its population has undergone bone reconstruction procedures $^{16,34}$. In private practice, costs are associated to the loyalty of dentists to the use of bone grafts ${ }^{33}$.

Dentists may select therapeutic options that involve high cost, based on their perception of the patient's profile and oral condition or on the patient's feedback regarding motivation or being able to afford the cost of the treatment ${ }^{35}$. The current study highlighted the low level of patient participation in the choice of material to be grafted, in contrast to most international studies ${ }^{29-31,35}$. This emphasizes the need to improve professional interaction with patients in order to make successful joint decisions regarding the use of bone graft.

High occurrence of inflammation or infection in grafted patients was proportional to high density of surgical care performed by the respondents. The rigid biosafety involved in processing, sterility and standardized validation tests of grafting ${ }^{12,36}$ reduces fears regarding the transmission of animal or human diseases ${ }^{30,31}$ and increases the safety perceived by dentists regarding their use ${ }^{37}$. Nevertheless, grafting procedure failure can range from 5 to $10 \%$ as a result of infections or inappropriate graft stabilization ${ }^{15}$. Factors such as filling large bone defects with bone block, mixed grafts (autogenous + synthetic) and diabetes mellitus may also be associated with 
infections ${ }^{38}$. To reduce potential out-of-office complications with bone grafting, it can be helpful to apply antibiotic therapy used sparingly ${ }^{39}$ and intensification of care with oral hygiene habits ${ }^{34}$.

Although there is still little dental use of bone grafts in Sobral, their cost-effectiveness and biosafety are

\section{FUNDING}

Our special thanks to Ceara State Foundation of Support for Scientific and Technological Development for financial support. FUNCAP-Brazil protocols: \#BP3-0139-00270.01.00/18 and \#88881.166822/2018-01.

\section{REFERENCES}

1. Horowitz RA, Leventis MD, Rohrer MD, Prasad HS. Bone Grafting: History, Rationale, and Selection of Materials and Techniques. Compend Contin Educ Dent 2014;35:1-7.

2. Pan S, Liu B, Min Y, Sun J, Zhai B, Guo XH. PreRegistration Assessment of Bone-Filling Products. Orthop Surg 2019;11:1-5.

3. Castro-Silva II, Zambuzzi WF, Granjeiro JM. Current overview of the use of xenograft in dentistry [portuguese]. Innov Implant J Biomater Esthet 2009;4:70-75.

4. Grado GF, Keller L, Idoux-Gillet Y, Wagner Q et al. Bone substitutes: a review of their characteristics, clinical use, and perspectives for large bone defects management. J Tissue Eng 2018;9:1-18.

5. Zizzari VL, Zara S, Tetè G, Vinci R, Gherlone E, Cataldi A. Biologic and clinical aspects of integration of different bonesubstitutes in oral surgery: a literature review. Oral Surg Oral Med Oral Pathol Oral Radiol 2016; 122:392-402.

6. Sousa SB, Castro-Silva II, Coutinho LACR, Lenharo A, Granjeiro JM. Osteoconduction and bioresorption of bone allograft versus anorganic bovine bone xenograft: a histomorphometric study in humans. J Biomim Biomater Tissue Eng 2013;18:85-95.

7. Singh R, Mahesh L, Shukla S. Infections Resulting from Bone Grafting Biomaterials. Int J Oral Implantol Clin Res 2013;4:68-71.

8. Castro-Silva II, Guerrero JAP, Gomes MJP, Souza Filho MSM. Biotechnological potential of by-products of the Brazilian animal protein industry in the generation of xenogeneic biomaterials for bone regeneration. Trends Res 2018;1:1-2.

9. Lomelino RO, Castro-Silva II, Linhares AB, Alves GG et al. The association of human primary bone cells with biphasic calcium phosphate ( $\beta \mathrm{TCP} / \mathrm{HA} 70: 30)$ granules increases bone repair. J Mater Sci Mater Med 2012;23:781-788.

10. Titsinides S, Agrogiannis G, Karatzas T. Bone grafting materials in dentoalveolar reconstruction: A comprehensive review. Jpn Dent Sci Rev 2019;55:26-32.

11. Hasan A, Byambaa B, Morshed M, Cheikh MI, Shakoor RA, Mustafy T, Marei HE. Advances in osteobiologic materials for bone substitutes. J Tissue Eng Regen Med $2018 ; 12: 1448-1468$ generally satisfactory and in accordance with the literature. This study confirms good acceptance by dentists and their knowledge of the subject of bone grafts in Sobral, a medium-sized city in the Brazilian inland, which constitutes a promising scenario for the development of the sector.

\section{CORRESPONDENCE}

Dr. Igor Iuco Castro-Silva

Avenida Comandante Maurocélio Rocha Ponte, 100 - Bloco de Laboratório da Pós-graduação / Laboratório de Biomateriais, Jocely Dantas de Andrade Torres, Sobral, Ceará, Brasil.CEP 62042-280

igor.iuco@sobral.ufc.br

12. Maximize Market Research. Global dental bone graft substitutes market - Global industry analysis and forecast (2018-2026) - by product, application, material and region. URL: http://www.maximizemarketresearch.com/marketreport/dental-bone-graft-substitutes-market/13027.

13. Persistence Market Research. Global market study on dental biomaterials: collaborations by manufacturers to increase consumer base anticipated to propel revenue growth. URL: http://spacemarketnow.com/301752/global-market-studyon-dental-biomaterials-collaborations-by-manufacturersto-increase-consumer-base-anticipated-to-propel-revenuegrouth.

14. Zion Market Research. Global dental bone graft substitutes market worth reach USD 931 million by 2025. URL: http://menafn.com/1098701890/Global-Dental-BoneGraft-Substitutes-Market-Worth-Reach-USD-931-MillionBy-2025.

15. Coherent Market Insights. Latin America bone graft and substitutes market, by product type (Bone graft (Allografts and Xenografts) and bone graft substitutes (Ceramics, Composites, Polymers, Bone Morphogenetics Proteins, and Others), by application (Spinal Fusion, Dental Bone Grafts, Craniomaxillofacial, Joint Reconstruction, and Trauma), and by country (Colombia, Peru, Chile, and Rest of Latin America) - size, share, outlook, and opportunity analysis, 2018-2026. URL: http://www.coherentmarketinsights.com/ market-insight/latin-america-bone-graft-and-substitutesmarket-2644.

16. MedSuite. Brazil market report suite for dental bone graft substitutes and other biomaterials 2017. URL: http://www. researchandmarkets.com/reports/4457188/brazil-marketreport-suite-for-dental-bone-graft\#pos-0.

17. Instituto Brasileiro de Geografia e Estatística. Censo populacional Sobral-CE. URL: http://cidades.ibge.gov.br/ brasil/ce/sobral.

18. Prefeitura municipal de Sobral-CE. Plano Municipal de Saúde - 2018-2021. URL: http://www.sobral.ce.gov.br.

19. Castro-Silva II, Coutinho LACR. Use of bone grafts in Dentistry: profile of dentists from Niteroi/RJ [portuguese]. Rev Bras Odontol 2012;69:154-158.

20. Exame. Brasil é o país com mais dentistas no mundo, 
mas ainda existem áreas de tratamento pouco exploradas e regiões com carência de profissionais. URL: http:// exame.abril.com.br/negocios/dino/brasil-e-o-pais-commais-dentistas-no-mundo-mas-ainda-existem-areas-detratamento-pouco-exploradas-e-regioes-com-carencia-deprofissionais.

21. Paulo AO, Castro-Silva II, Oliveira DF, Machado MEL, Bonetti-Filho, Granjeiro JM. Repair of critical-size defects with autogenous periosteum-derived cells com $\neg$ bined with bovine anorganic apatite/collagen: an experimental study in rat calvaria. Braz Dental J 2011;22: 322-328.

22. Berberi A, Samarani A, Nader N, Noujeim Z et al. Physicochemical characteristics of bone substitutes used in oral surgery in comparison to autogenous bone. BioMed Res Int 2014; 2014:1-9.

23. Kattimani VS, Lingamaneni PS. Natural bioceramics: our experience with changing perspectives in the reconstruction of maxillofacial skeleton. J Korean Assoc Oral Maxillofac Surg 2019;45:34-42.

24. Gonçalves F, Hohn A, Granjeiro JM, Castro-Silva II, Taga $\mathrm{R}$, Cestari TM. Bone regeneration in Dentistry with use of composed bone substitute Gen Mix [portuguese]. Implant News 2009; 6: 373-379.URL: https://www.researchgate. net/publication/285976134

25. Papageorgiou SN, Papageorgiou PN, Deschner J, Götz W. Comparative effectiveness of natural and synthetic bone grafts in oral and maxillofacial surgery prior to insertion of dental implants: Systematic review and network metaanalysis of parallel and cluster randomized controlled trials. J Dent 2016;48:1-8.

26. MedSuite. Dental bone graft substitutes market analysis, size, trends Brazil 2017-2023. URL: http://idataresearch. com/product/dental-bone-graft-substitutes-market-brazil.

27. Ponte JS, Araújo MAD, Araújo LK, Castro-Silva II. Platelet-Rich Fibrin: A Versatile Purpose for Alveolar Ridge Preservation. Dent Oral Biol Craniofac Res 2019;2:2-3.

28. Wang W, Yeung KWK. Bone grafts and biomaterials substitutes for bone defect repair: A review. Bioact Mater 2017;2:224-247.

29. Almutairi AS. A descriptive analysis of patient's preferences in bone graft therapy in dentistry. Int J Health Sci 2019; 13:24-28.
30. Fernández RF, Bucchi C, Navarro P, Beltrán V, Borie E. Bone grafts utilized in dentistry: an analysis of patients' preferences. BMC Med Ethics 2015;16:1-7.

31. Agrawal N, Gupta ND, Tewari1 RK, Garg AK, Yadav P. Patients' perception about dental implant and bone graft surgery: A Questionnaire-Based Survey. J Indian Assoc Public Health Dent 2017;15:258-262.

32. Castro-Silva II, Lima FMS, Granjeiro JM. Bone grafts in Brazilian Dentistry: overview, challenges and prospects on the vision of Health Management [portuguese]. Rev Flum Odontol 2013;1:63-71. URL: https://periodicos.uff.br/ijosd/ article/view/30431/17665

33. Rančić J, Rančić N, Majstorović N, Biočanin V, Milosavljević M, Jakovljević M. Cost diferentials of dental outpatient care across clinical dentistry branches. Farmeconomia Health Econ Ther Pathways 2015;16:25-32.

34. Conselho Federal de Odontologia. Saúde Bucal-Pesquisa Datafolha 2014. URL: http://cfo.org.br/wpcontent/uploads/ 2014/11/HábitosAtitudeseComportamentosnaSaúdeBucal. pdf.

35. Vernazza CR, Rousseau N, Steele JG, Ellis JS, Thomason JM, Eastham J, Exley C. Introducing high-cost health care to patients: dentists' accounts of offering dental implant treatment. Community Dent Oral Epidemiol 2015;43:7585.

36. Ortega-Lopes R, Andrade VC, Nóia CF, Cidade CPV, Chaves-Netto HDM, Mazzonetto R. Retrospective four year analysis in 199 bone grafts of the alveolar ridge. Rev Gaúcha Odontol 2012;60:79-83. URL: http://revodonto. bvsalud.org/pdf/rgo/v60n1/a11v60n1.pdf

37. Bugarin Júnior JG, Garrafa V. Bioethics and biosafety: the use of biomaterials in dental practice. Rev Saúde Pública 2007;41:223-228. URL: https://www.scielo.br/pdf/rsp/ v41n2/en_5411.pdf

38. Kaing L, Grubor D, Chandu A. Assessment of bone grafts placed within an oral and maxillofacial training programme for implant rehabilitation. Aust Dent J 2011;56:406-411.

39. Lee JW, Lee JY, Kim SM, Lee JH. Prophylactic antibiotics in intra-oral bone grafting procedures: a prospective, randomized, double-blind clinical trial. J Korean Assoc Oral Maxillofac Surg 2012;38:90-95. 